\title{
STUDY ON POZZOLANA ACTIVITY OF WHEAT STRAW ASH AS POTENTIAL ADMIXTURE FOR BLENDED CEMENTS
}

\author{
\#ONDŘEJ JANKOVSKÝ*, MILENA PAVLÍKOVÁ**, DAVID SEDMIDUBSKÝ*, DANIEL BOUŠA*, \\ MICHAL LOJKA*, JAROSLAV POKORNÝ**, MARTINA ZÁLESKÁ**, ZBYŠEK PAVLÍK** \\ *Department of Inorganic Chemistry, Faculty of Chemical Technology, University of Chemistry and Technology, \\ Technická 5, 16628 Praha 6, Czech Republic \\ **Department of Materials Engineering and Chemistry, Faculty of Civil Engineering, Czech Technical University in Prague, \\ Thákurova 7, 16629 Prague 6, Czech Republic \\ "E-mail: Ondrej.Jankovsky@vscht.cz
}

Submitted May 10, 2017; accepted July 4, 2017

\begin{abstract}
Keywords: Biomass combustion, Wheat straw ash, Chemical and physical analysis, Pozzolana activity, Cement blends, Strength activity index

Wheat straw ash coming from combustion of packed wheat straw was studied as a potential pozzolana active admixture for blended cements. X-Ray fluorescence, X-Ray diffraction, scanning electron microscopy, and energy dispersive spectroscopy were used to examine chemical and mineralogical composition, morphology and elemental distribution of a raw untreated ash. Due to high carbon content, the wheat straw ash was thermally treated for 2 hours at $700^{\circ} \mathrm{C}$ and analyzed again using the same analytic techniques. Thermal treatment process was monitored using simultaneous thermal analysis and Fourier Transform infrared spectroscopy. The pozzolana activity was assessed using Chapelle and Frattini tests. In the next step, wheat straw ash was used for preparation of blended cement pastes. The content of ash in the blends was 10, 15, and $20 \%$ by mass. For the hardened pastes, basic physical properties, mechanical parameters, and pore size distribution were measured. For fresh past mixes, workability was tested. Moreover, leachability of chlorides, nitrates, sulfates and alkalis from paste samples was studied. The experimentally obtained data pointed to the high pozzolana activity of wheat straw ash and sufficient mechanical properties of cement pastes with the ash content up to 20 mass \% of cement. In summary, the analyzed waste product from biomass combustion was found to be applicable as a part of cement-based blended binder providing economic and environmental benefits for concrete industry.
\end{abstract}

\section{INTRODUCTION}

De-carbonising global electricity generation is seen as key to stabilise atmospheric greenhouse gas levels [1]. Biomass production for use in electricity generation is considered as a renewable energy source that can contribute to the mitigation of climate change through the direct $\mathrm{CO}_{2}$ sequestration and through the replacement of higher $\mathrm{CO}_{2}$ emitting fuels such as coal and oil. The use of biomass to produce electricity has steadily increased by an average of 13 TWh per year between 2000 and 2008 [2]. In 2009, there were a total of 62 countries in the world producing electricity from biomass. Among them, the USA was the dominant biomass electricity producer at $26 \%$ of world production, followed by Germany (15\%), Brazil and Japan (both $7 \%$ ) [2]. In 2012, the use of biomass was widespread globally, producing $280 \mathrm{TWh}$ of electricity, equivalent to $1.5 \%$ of global electricity generation per annum [3]. Today, biomass is the most widely used renewable energy source in the world today.

Bioenergy can be produced from a variety of biomass feed stocks, including forest, agricultural and livestock residues; short-rotation forest plantations; energy crops; the organic component of municipal solid waste; and other organic waste streams [4]. Through a variety of processes, these feed stocks can be directly used to produce electricity or heat, or can be used to create gaseous, liquid, or solid fuels. Some commercially available technologies include small- and large-scale boilers, domestic pellet-based heating systems, and ethanol production from sugar and starch [5].

Since the production of energy from biomass combustion is continuously increasing, the processing and disposal of the resulting ash has become an environmental and economic issue. It is estimated that approximately 480 million tonnes of biomass ash (BA) could be generated worldwide annually [6]. This quantity is comparable to that of coal ash, namely 780 million tonnes produced per year at present [7].

$\mathrm{BA}$ is the solid residue produced during the incineration of plant biomass for heat and electricity production and represents $\sim 2-20 \%$ of the input material [8]. The composition of BA differs considerably, even within the same facility, because the physical and chemical characteristics depend strongly on plant type, origin and parts used for combustion, the process parameters, and the storage conditions. Approximately 229 forming, major, minor and accessory phases or minerals were identified in BAs [6]. Ash contains valuable macro- and micronutrients from the combusted biomass and thus 
requires a suitable recycling strategy. Because of its value, nowadays, biomass ash is usually disposed of in landfills, creating significant costs for biomass plant operators [9]. Biomass ash has many potential areas of application: in forest ecosystems to return nutrients to harvested fields or to counteract soil acidification, for agricultural and horticultural purposes as fertilizer, and for geotechnical construction and industrial processes [10]. Typical applications in this last field are the construction of roads, surface layer in landfills, and admixture of ash to concrete, brick or cement production $[9,11,12]$. The production of construction materials (particularly cement and concrete plus many other building materials) currently offers the biggest utilisation opportunities for BA despite some technical, commercial and environmental barriers [13, 14]. This is due to the enrichment of BAs with numerous active, semi-active and pozzolana phases with cement and binding behaviour during hydration-dehydration and hydroxylation-dehydroxylation of BA [10].

Today supplementary cementitious materials (SCMs) are widely used in concrete either in blended cements or added separately in the concrete mixer [15], [16]. The use of such materials, where no additional clinkering process is involved, leads to a significant reduction in $\mathrm{CO}_{2}$ emissions per ton of cementitious materials (grinding, mixing and transport of concrete use very little energy compared to the clinkering process) and is also a means to utilize by-products of industrial manufacturing processes [17]. Therefore, research on application of BA in concrete and cement industry is of the particular importance both from the economic and environmental point of view. Presently, the lack of enough knowledge and data currently appears to be one of the biggest problems for the future innovative and sustainable large-scale management of BA. Many more complete and detailed investigations are required to reach the level of knowledge achieved for coal ashes that are presently applied worldwide as SCMs. In order to fully understand BA potential, it is of vital importance to gain better fundamental knowledge of the composition and properties of biomass and BA. Therefore, a lot of future work related to systematic studies of biomass and BA is needed.

In this paper, wheat straw ash (WSA) was studied as a potential pozzolana active admixture for blended cements. WSA as well as blended binder pastes were studied in detail by various analytic methods to examine chemical and mineralogical composition, morphology, elemental distribution, pozzolana activity, basic physical properties, mechanical parameters and pore size distribution. Due to high carbon content of WSA we tested the possibility of thermal treatment. Thermal treatment process was monitored using simultaneous thermal analysis and Fourier Transform infrared spectroscopy. Moreover, leachability of chlorides, nitrates, sulfates and alkalis from paste samples was studied. The potential use of WSA coming from combustion of packed wheat straw as SCMs in mortars and concrete was studied with the objective to recover valuable raw material from industrial waste, allowing the development of a 'greenerconcrete' with a reduced environmental impact and lower embodied energy compared to the current one.

\section{EXPERIMENTAL}

\section{Materials and samples preparation}

The wheat straw ash was obtained from Žlutice heating plant, Czech Republic. Due to the high carbon content, the raw biomass ash was thermally treated in a furnace in a static air atmosphere for 2 hours at $700^{\circ} \mathrm{C}$. The heating and cooling rate was set at $8^{\circ} \mathrm{C} \cdot \mathrm{min}^{-1}$. Sample before the treatment was termed WSA, while treated sample was termed WSA-T. Since the thermal treatment negatively affected specific surface and thus pozzolana activity of WSA-T, raw WSA was used for preparation of cement blends and casting paste samples. The content of WSA in paste mixes was 10, 15, and 20 mass $\%$ of cement respectively. As a main binder, Portland cement CEM I 42.5 R produced in cement factory Radotín, Českomoravský cement, Heidelberg Cement Group, Czech Republic, was used. Its chemical composition and basic material parameters provided by producer are given in Tables 1, 2. The water/binder ratio was 0.4 and was similar for all paste mixes. Since the fineness of a raw WSA was not sufficient, it was grinded for $15 \mathrm{~min}$ using a vibratory disc mill.

Table 1. Chemical composition of cement (mass \%).

\begin{tabular}{cc}
\hline Substance & CEM I 42.5 R, Radotín \\
\hline $\mathrm{SiO}_{2}$ & 19.00 \\
$\mathrm{Al}_{2} \mathrm{O}_{3}$ & 4.31 \\
$\mathrm{Fe}_{2} \mathrm{O}_{3}$ & 2.40 \\
$\mathrm{TiO}_{2}$ & 0.28 \\
$\mathrm{CaO}$ & 62.90 \\
$\mathrm{MgO}$ & 1.80 \\
$\mathrm{~K}_{2} \mathrm{O}$ & 0.82 \\
$\mathrm{Na}_{2} \mathrm{O}$ & 0.14 \\
$\mathrm{SO}_{3}$ & 3.24 \\
\hline
\end{tabular}

Table 2. Basic properties of CEM I 42.5 R (Radotín).

\begin{tabular}{ccc}
\hline $\begin{array}{c}\text { Blain specific } \\
\text { surface }\left(\mathrm{m}^{2} \cdot \mathrm{kg}^{-1}\right)\end{array}$ & $\begin{array}{c}\text { Matrix density } \\
\left(\mathrm{kg} \cdot \mathrm{m}^{-3}\right)\end{array}$ & $\begin{array}{c}\text { Loss on ignition } \\
\text { at } 1000^{\circ} \mathrm{C}[\%]\end{array}$ \\
\hline 360 & 3129 & 3.1 \\
\hline
\end{tabular}

The samples prepared were rectangular prisms having the dimension of $40 \mathrm{~mm} \times 40 \mathrm{~mm} \times 160 \mathrm{~mm}$. The casted samples were stored for $24 \mathrm{~h}$ in a highly humid environment of approx. $98 \% \mathrm{RH}$ and after demolding cured for 27 days in water having tempera- 
ture of $23 \pm 2{ }^{\circ} \mathrm{C}$. For initial curing, removal from molds and water curing we followed ASTM standard C 192/C 192 M - 06 [18]. The water curing was done in accordance with ASTM C511 [19].

For all experiments, we used distilled water (16.8 M $\Omega$ ) except of the preparation of paste samples, where tap water was used. Distilled water was used in order to avoid the contamination of samples by various ions, especially chlorides. We also used $\mathrm{HCl}$ (35\%, PENTA, Czech Republic, p.a.) NaOH (PENTA, Czech Republic, p.a.) and EDTA (PENTA, Czech Republic, p.a.).

\section{WSA and WSA-T tests}

$\mathrm{X}$-Ray fluorescence analysis (XRF) was performed using an Axios sequential WD-XRF spectrometer (PANalytical, Nederland) equipped with an $\mathrm{Rh}$ anode end-window X-ray tube fitted with a $50 \mu \mathrm{m}$ beryllium window. The resulting data were collected by SuperQ software and further evaluated by Omnian software. The analyzed ashes were pressed, without any binding agent, onto $\mathrm{H}_{3} \mathrm{BO}_{3}$ pellets with a total thickness of approximately $5 \mathrm{~mm}$ and a diameter of $40 \mathrm{~mm}$. The pellets were then covered with a $4 \mu \mathrm{m}$ supporting polypropylene (PP) film.

The morphology was investigated using scanning electron microscopy (SEM) with a FEG electron source (Tescan Lyra dual beam microscope). Elemental composition and mapping were performed using an energy dispersive spectroscopy (EDS) analyzer $\left(\mathrm{X}-\mathrm{Max}^{\mathrm{N}}\right)$ with a $20 \mathrm{~mm}^{2}$ SDD detector (Oxford instruments) and AZtecEnergy software. To conduct the measurements, the samples were placed on a carbon conductive tape. SEM and EDS measurements were carried out using a 10 $\mathrm{kV}$ electron beam.

X-ray powder diffraction data were collected at room temperature on a Bruker D8 Discoverer powder diffractometer with parafocusing Bragg-Brentano geometry using $\mathrm{CuK}_{\alpha}$ radiation $(\lambda=0.15418 \mathrm{~nm}, \mathrm{U}=40 \mathrm{kV}$, $\mathrm{I}=40 \mathrm{~mA})$. Data were scanned over the angular range $5-80^{\circ}(2 \theta)$ with a step size of $0.019^{\circ}(2 \theta)$. The crystallinity of the sample was calculated using Rietveld refinement in Topaz software.

Thermal behavior of the biomass ash treatment was analyzed by Simultaneous thermal analysis (STA). The DTA and TG curves were recorded simultaneously on a Linseis STA PT1600 apparatus at a heating rate of $8^{\circ} \mathrm{C} \mathrm{m^{-1 }}$ in a dynamic air atmosphere $\left(50 \mathrm{ml} \cdot \mathrm{min}^{-1}\right)$.

Particle size distribution was measured because of the evident effect of the fineness of pozolanic material on its pozzolana activity and reactivity with cement hydrates. In this test, WSA and WSA-T samples grinded for 15 min using a vibratory disc mill were analyzed. The measurement was done on a laser diffraction principle using the device Analysette 22 MicroTec plus (Fritsch).

As basic physical characteristics of analyzed ashes, their matrix density, bulk density and specific surface were measured. The powder density was access on a gra- vimetric principle from the measured sample mass and volume. The matrix density was measured by helium pycnometry, using a Pycnomatic ATC apparatus (Thermo Scientific). The specific surface was accessed using Blain apparatus according to the standard EN 196-6 [20]. Additionally, BET specific surface was measured using a sorption analyzer Coulter SA 3100 (Backman Coulter). The samples were outgassed for 4 hours at $150^{\circ} \mathrm{C}$ under high vacuum (VALUE) prior to the sorption experiments. A TCD nitrogen cooled $(77 \mathrm{~K})$ detector was used for the evaluation of the results using BET (Brunauer, Emmett and Teller) and Kelvin equations.

Another test performed for the raw and thermally treated WSAs was aimed at the specification of the amount of leachable salts. The leaching tests were done according to EN 12457-2 [21]. The liquid/solid ratio was $10 \mathrm{l} \cdot \mathrm{kg}^{-1}$. In our experiments, $100 \mathrm{ml}$ of distilled water was used for leaching of $10 \mathrm{~g}$ of ash samples. The leaching was realized for $24 \mathrm{~h}$. The content of chlorides, nitrates, sulfates and alkalis was measured using a liquid-solid adsorption chromatograph with a conductivity detector Shodex CDe5. The $\mathrm{pH}$ of a particular leachate was accessed using a laboratory $\mathrm{pH}$ meter inoLab $740 \mathrm{pH} /$ Ion (WTW).

Both the raw and thermally treated milled WSAs were studied using Frattini and modified Chapelle tests in order to determine their pozzolana activity. The Frattini test was based on a comparison of the amount of $\mathrm{Ca}(\mathrm{OH})_{2}$ present in the liquid phase in contact with cement with the amount of $\mathrm{Ca}(\mathrm{OH})_{2}$ that saturates the environment of equal alkalinity. The analysis was done according to ČSN EN 196-5 [22]. The tested mixes were prepared using Portland cement CEM I 42.5 R that was replaced by 10,15 , and 20 mass $\%$ with the tested BAs. Results were presented as a graph of $\left[\mathrm{Ca}^{2+}\right]$ expressed as equivalent of $\mathrm{CaO}\left[\mathrm{mmol} \mathrm{l}^{-1}\right]$ on the y-axis versus $\left[\mathrm{OH}^{-}\right]$ $\left[\mathrm{mmol} \cdot \mathrm{l}^{-1}\right]$ on the $\mathrm{x}$-axis. Based on the principle of the test method, a material exhibits pozzolana activity if the results of tested mixes are situated below the solubility curve of $\mathrm{Ca}(\mathrm{OH})_{2}$ which indicates removing of $\mathrm{Ca}^{2+}$ from the solution. The modified Chapelle test was carried out using the procedure described in the French norm NF $\mathrm{P}$ 18-513 [23]. The principle of the method was based on the reaction of $1 \mathrm{~g}$ of tested powder material with $2 \mathrm{~g}$ $\mathrm{CaO}$ in the water. The results were expressed in $\mathrm{mg}$ $\mathrm{Ca}(\mathrm{OH})_{2}$ fixed by the $1 \mathrm{~g}$ of tested sample and gave the straight information about pozzolana activity. As referred by Pokorný et al. [24], the minimum amount of $\mathrm{Ca}(\mathrm{OH})_{2}$ fixed by a material should be $650 \mathrm{mg} \cdot \mathrm{g}^{-1}$ to consider it as pozzolanic.

\section{Application of WSA in pastes based on cement blends}

For fresh paste mixes, a flow table test was done. Moreover, initial and final setting times were monitored using automatic Vicat's apparatus according to the technical standard EN 196-3 [25]. 
The testing of hardened paste samples included assessment of basic physical properties, pore size distribution, mechanical properties, and leaching tests. In order to evaluate the pozzolana activity of WSA in blended cement binder, STA and Fourier Transform Infrared spectroscopy (FT-IR) were used.

The bulk density was determined using the measurement of sample sizes and dry mass of the sample. The expanded combined uncertainty of the bulk density test was $2.4 \%$. The matrix density was obtained by helium pycnometry (see above). On the basis of bulk density and matrix density measurements, the total open porosity was calculated [26]. The expanded combined uncertainty of the total open porosity test was $3 \%$.

For the measurement of pore size distribution, mercury porosimeters Pascal 140 and Pascal 440 (Thermo Scientific) were used. At the evaluation of measured data, the circular cross section of capillaries was assumed.

Among the mechanical parameters of the prepared pastes, flexural strength, compressive strength and Young's modulus of elasticity were measured. Both strength tests were done using the procedure described in EN 196-1 [27]. The flexural strength was determined for prisms having the dimension of $40 \times 40 \times 160 \mathrm{~mm}$. The compressive strength was measured on fragments of samples from flexural strength testing. The loading area was $40 \times 40 \mathrm{~mm}$. The relative expanded uncertainty of the compressive and flexural strength tests was $1.4 \%$. The Young's modulus was obtained on a dynamic principle using the pulse ultrasonic method. This method is based on the measurement of travel time of ultrasonic wave launched from the device and passing through the material. The measurement was done on $40 \times 40 \times 160 \mathrm{~mm}$ prismatic samples in a longitudinal direction using device DIO 562 (Starmans electronics) working on a frequency of $50 \mathrm{KHz}$ [28]. The relative expanded uncertainty of the dynamic Young's modulus measurement was $2 \%$. Before the ultrasonic measurement and determination of basic physical properties, the samples were dried in a vacuum oven at $105^{\circ} \mathrm{C}$.

For the hardened cement paste samples, the leaching tests were performed on milled samples $(10 \mathrm{~g})$ that were immersed in $100 \mathrm{ml}$ of distilled water for $24 \mathrm{~h}$. In these tests, similar experimental procedure was followed as described above for testing the leachability of WSAs. Pozzolana activity of WSA in cement blend mixes was monitored by STA that was performed using a Linseis STA PT1600 apparatus at a heating rate of $8^{\circ} \mathrm{C} \cdot \mathrm{min}^{-1}$ in a dynamic air atmosphere $\left(50 \mathrm{ml} \cdot \mathrm{min}^{-1}\right)$.

In order to evaluate the contribution of WSA admixture in formation of cement paste solid structure, FT-IR spectrometer Nicolet 6700 (Thermo Fischer Scientific) in ATR regime was used. The measuring device consisted of He-Ne laser, high-intensity IR source EverGlo $^{\mathrm{TM}}$, GE/KBr beam splitter, golden mirrors, pyroelectric detector HP DLaTGS and interchangeable sample compartment. This type of FT-IR spectrometer operates in a spectral range from 7800 to $350 \mathrm{~cm}^{-1}$ with spectral resolution $0.4 \mathrm{~cm}^{-1}$. Spectra were collected after 32 scans in absorbance mode using ATR diamond crystal. The samples tested after 28 days of hardening were prepared in the form of dry powder. The spectral regions were normalized to enable comparison of individual samples.

\section{RESULTS AND DISCUSSION}

The chemical composition of WSA before and after thermal treatment analyzed by XRF is presented in Table 3. The sample WSA contained, except of $\mathrm{C}$, high amount of $\mathrm{Si}, \mathrm{K}, \mathrm{Ca}, \mathrm{Mg}$ and $\mathrm{P}$. After the treatment, carbon content decreased. Decrease of carbon content can be visible from photography of ashes (Figure 1).

Table 3. Chemical composition of WSA and WSA-T (mass \%).

\begin{tabular}{crr}
\hline Substance, element & WSA & WSA-T \\
\hline $\mathrm{C}$ & 27.6 & 20.7 \\
$\mathrm{Na}_{2} \mathrm{O}$ & 0.1 & 0.1 \\
$\mathrm{MgO}$ & 2.5 & 2.7 \\
$\mathrm{Al}_{2} \mathrm{O}_{3}$ & 1.5 & 1.8 \\
$\mathrm{SiO}_{2}$ & 47.5 & 52.4 \\
$\mathrm{P}_{2} \mathrm{O}_{5}$ & 3.0 & 3.3 \\
$\mathrm{~S}$ & 1.1 & 1.2 \\
$\mathrm{Cl}$ & 0.3 & 0.2 \\
$\mathrm{~K}_{2} \mathrm{O}$ & 10.1 & 11.1 \\
$\mathrm{CaO}$ & 5.5 & 5.6 \\
$\mathrm{TiO}_{2}$ & 0.1 & 0.1 \\
$\mathrm{Fe}_{2} \mathrm{O}_{3}$ & 0.5 & 0.6 \\
$\mathrm{BaO}$ & 0.1 & 0.1 \\
\hline
\end{tabular}

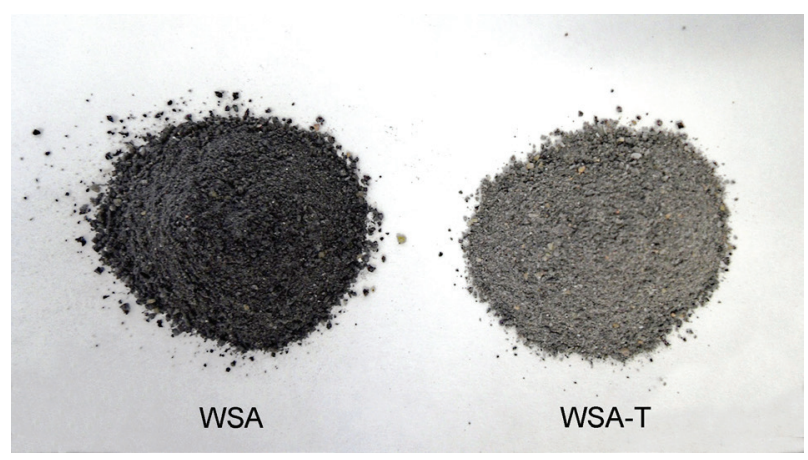

Figure 1. Wheat straw as before (WSA) and after thermal treatment (WSA-T).

The morphology of WSA analyzed using SEM is shown in Figure 2. Extremely large particles were found in both samples, which were caused by the presence of amorphous phase sintered together with crystalline phase. The morphology after the treatment remained almost unchanged. 


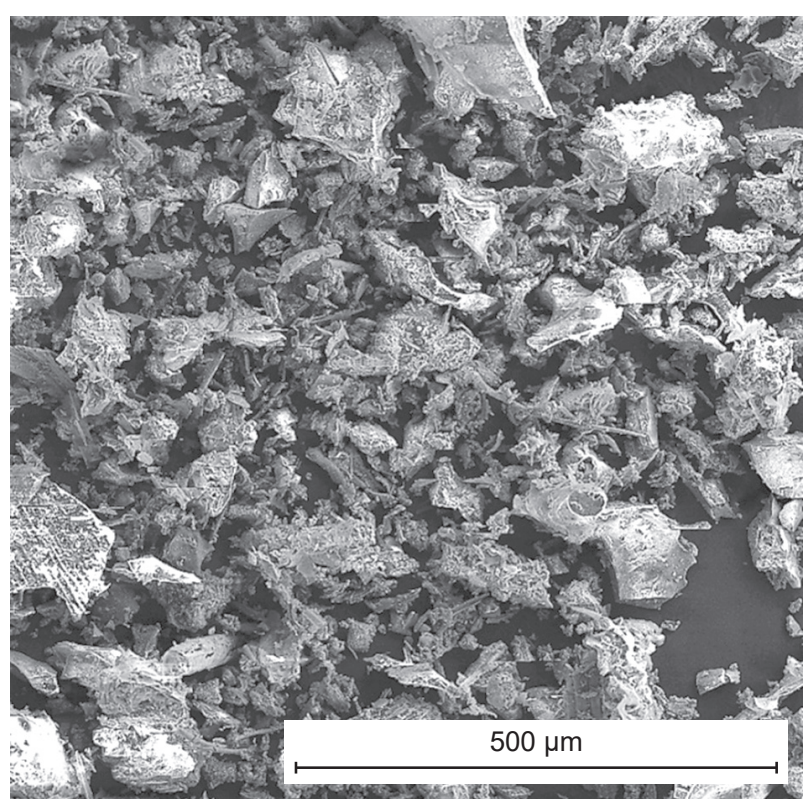

a) WSA



c) WSA-T

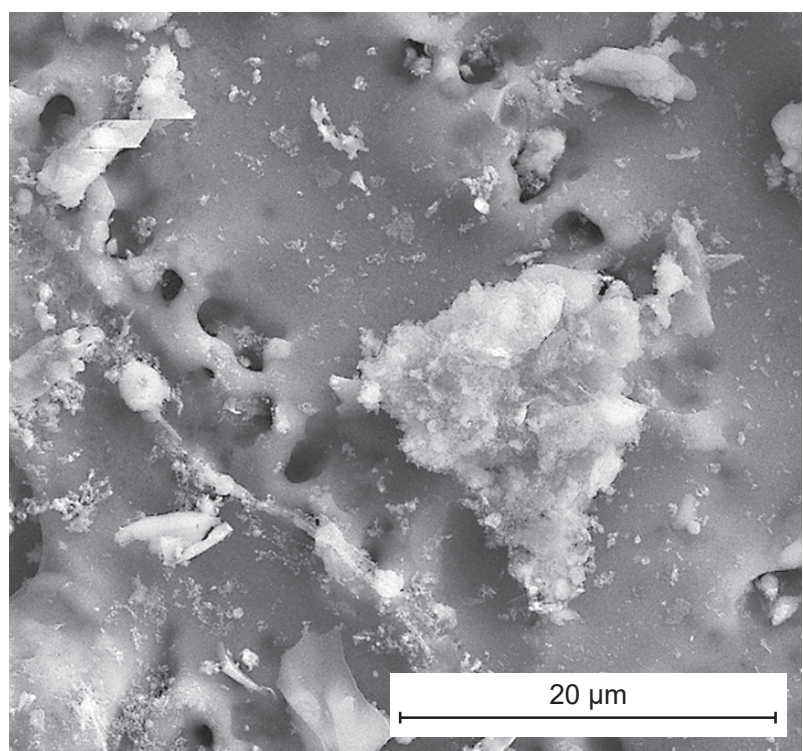

b) WSA

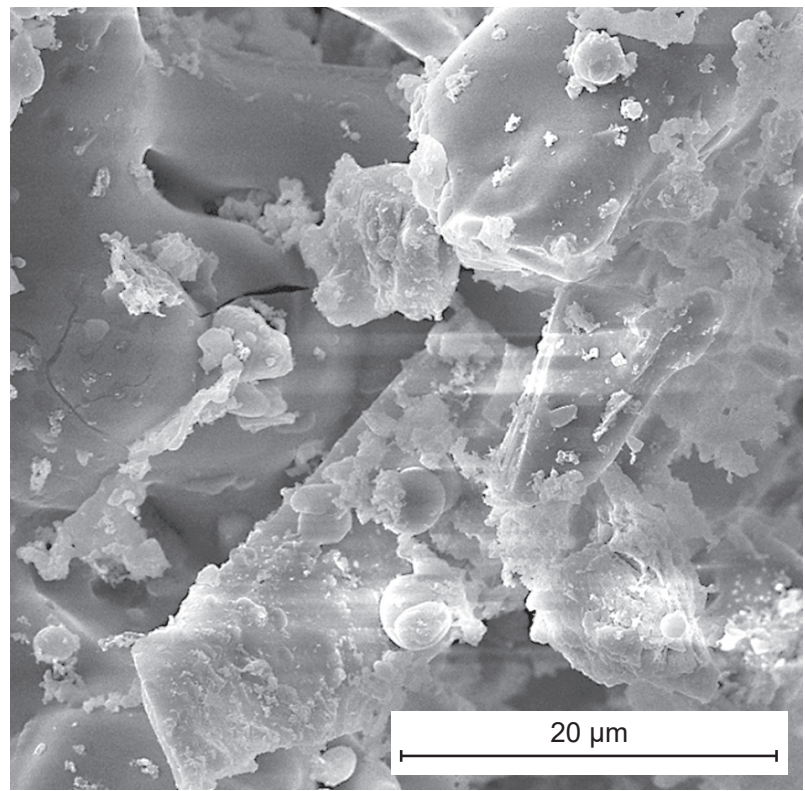

d) WSA-T

Figure 2. The morphology of wheat straw ash at various magnifications obtained by SEM.

The elemental distribution maps analyzed by energy dispersive spectroscopy are presented in Figure 3. Looking at these results, one can observe uniform distribution of the particular analyzed elements.

XRD diffraction patterns of WSA are presented in Figure 4. Wheat straw ash is partially amorphous and it contains two major phases: cristobalite and quartz. The amount of amorphous phase was determined from Rietveld refinement. The calculated value $\sim 75.9$ mass $\%$ obtained for WSA sample and $\sim 84.8$ mass $\%$ for WSA-T sample revealed the highly amorphous nature of the analyzed combustion residua.
The TG and DSC curves obtained for WSA sample during its thermal treatment are given in Figure 5. During the heating, one thermal effect was detected. This exothermal peak started at $\sim 300^{\circ} \mathrm{C}$ and reached its maximum at $\sim 440^{\circ} \mathrm{C}$. This effect was caused due to the oxidation/combustion of carbon, which was confirmed from weight decrease (see TG curve). The overall weight decrease during the carbon oxidation was $\sim 7$ mass \% which was in good agreement with results from X-Ray fluorescence.

The particle size distribution curves obtained for WSA and WSA-T 15 minutes milled using a vibratory 
disc mill are presented in Figures 6, 7. For comparative purposes, the particle size distribution parameters $\mathrm{d}_{90}, \mathrm{~d}_{50}$, and $\mathrm{d}_{10}$ are introduced in Table 4 . They were taken from cumulative curves graphed in Figure 7.
A comparison with CEM I $42.5 \mathrm{R}$ cement showed that the ash particles were coarser; the main peak at the particle size distribution curve was at $26.2 \mu \mathrm{m}$ for cement, $62.2 \mu \mathrm{m}$ for WSA, and $92.6 \mu \mathrm{m}$ WSA-T respectively.

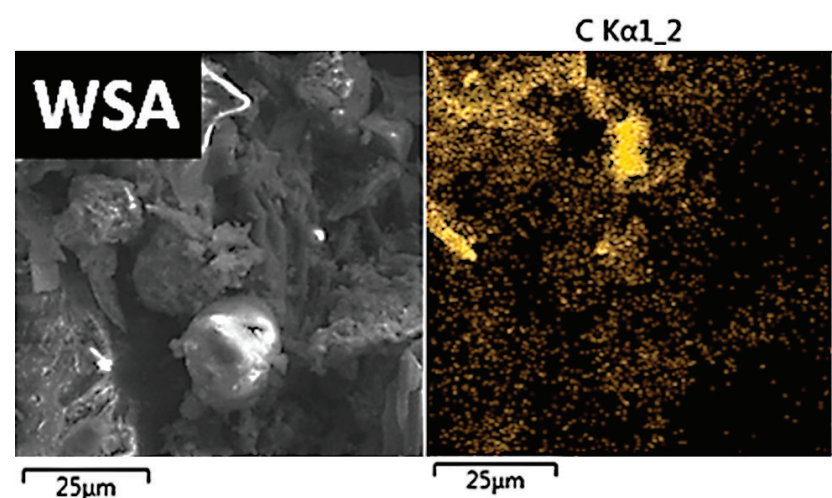

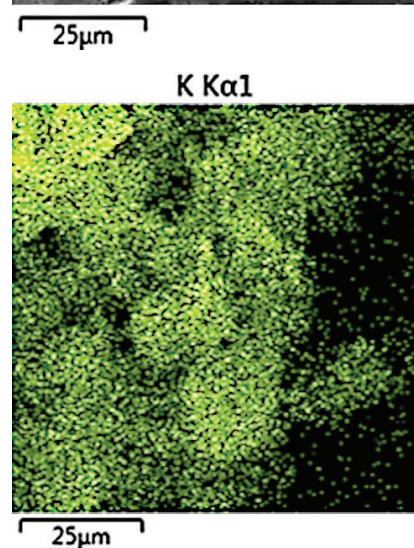

$\longdiv { 2 5 \mu \mathrm { m } }$
$\mathrm{P} K \alpha \mathbf{l}$



Si Kal



$25 \mu \mathrm{m}$

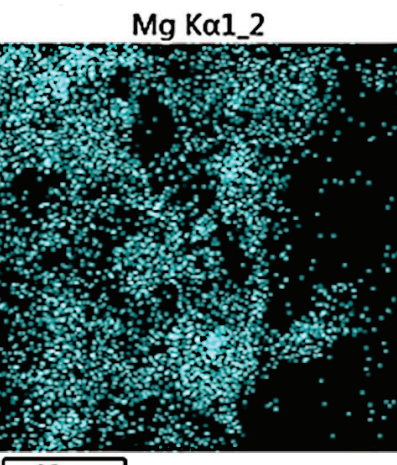

$25 \mu \mathrm{m}$
$\mathrm{OK} \alpha \mathbf{l}$

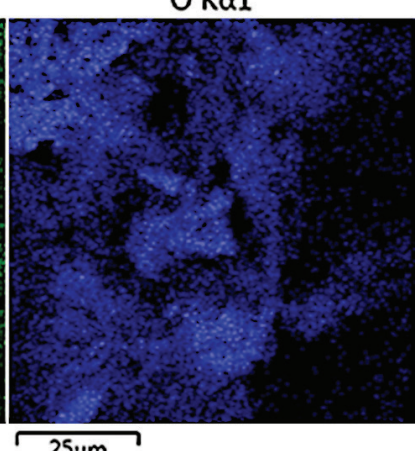

Ca $K \alpha 1$



$25 \mu \mathrm{m}$

a) WSA


b) WSA-T

Figure 3. Elemental distribution maps of wheat straw ash obtained by EDS, scale bar is $25 \mu \mathrm{m}$. 




Figure 4. X-Ray Diffraction patterns of wheat straw ash.

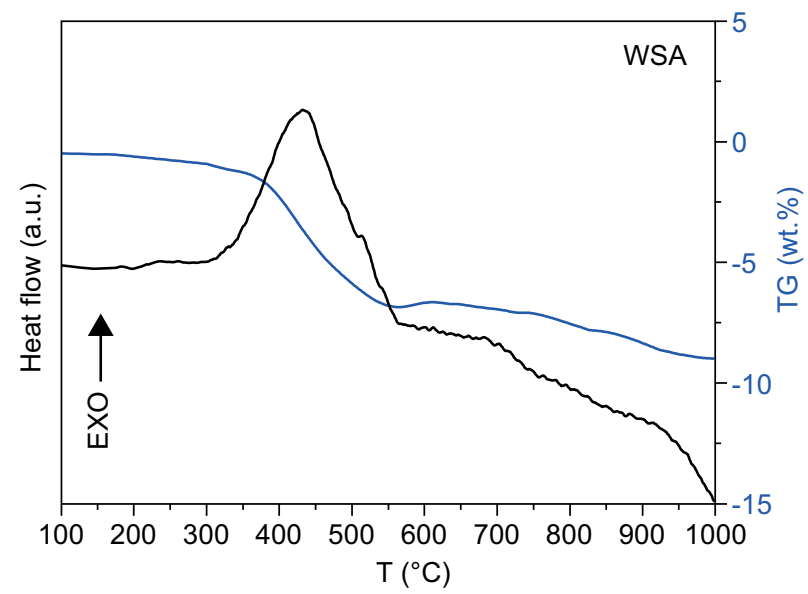

Figure 5. Thermal behavior of wheat straw ash during its heating.

Looking at Table 4, thermal treatment of WSA led to the coarsening of its particles compared to data obtained for untreated ash, although the milling time was similar for the both stated residua. This finding partially reduces the application potential of WSA-T in cement blends.

Basic physical and chemical characteristics of WSA and WSA-T samples are given in Table 5. Thermal treatment led to a significant reduction in both the Blain

Table 4. Particle size distribution - cumulative data.

\begin{tabular}{lccr}
\hline \multirow{2}{*}{ Material } & \multicolumn{3}{c}{ Size $(\mu \mathrm{m})$} \\
\cline { 2 - 4 } & $\mathrm{d}_{10}$ & $\mathrm{~d}_{50}$ & \multicolumn{1}{c}{$\mathrm{d}_{90}$} \\
\hline CEM I 42.5 R & 5.2 & 19.7 & 38.4 \\
WSA & 17.1 & 51.0 & 102.4 \\
WSA-T & 18.9 & 76.0 & 206.0 \\
\hline
\end{tabular}

fineness and BET specific surface, which limits their use as an active part of blended binder. On the other hand, $\mathrm{pH}$ values measured for leachate of WSA and WSA-T proved the estimated alkali character of wheat straw ash.

The results of leaching tests for soluble salts are presented in Table 6. The untreated ash exhibited high amount of leachable chlorides and nitrates and only trace amount of sulfates. In case of material WSA-T, thermal treatment reduced significantly amount of leachable chlorides, however, the amount of leachable nitrates remained high. Meira et al. [29] in their detailed literature overview reported the chloride threshold values in the range of $0.2-1.5$ mass $\%$ of cement. Considering the leachability of chlorides from both studied ashes and their chemical composition obtained by XRF, all the prepared pastes with Portland cement replacement can be considered as a safe solution from the point of view of possible corrosion of reinforcement. In Table 7 the alkali

Table 6. Results of leaching tests of raw and thermally treated wheat straw ash for soluble.

\begin{tabular}{lccc}
\hline Material & $\begin{array}{c}\text { Chlorides } \\
\left(\mathrm{mg} \cdot \mathrm{g}^{-1}\right)\end{array}$ & $\begin{array}{c}\text { Nitrates } \\
\left(\mathrm{mg} \cdot \mathrm{g}^{-1}\right)\end{array}$ & $\begin{array}{c}\text { Sulfates } \\
\left(\mathrm{mg} \cdot \mathrm{g}^{-1}\right)\end{array}$ \\
\hline WSA & 3.1 & 9.7 & 0.4 \\
WSA-T & 0.7 & 5.9 & 0.3 \\
\hline
\end{tabular}

Table 7. Results of leaching tests of raw and thermally treated wheat straw ash for alkalis.

\begin{tabular}{lccc}
\hline Material & $\begin{array}{c}\mathrm{Na}_{2} \mathrm{O} \\
\left(\mathrm{mg} \cdot \mathrm{g}^{-1}\right)\end{array}$ & $\begin{array}{c}\mathrm{K}_{2} \mathrm{O} \\
\left(\mathrm{mg} \cdot \mathrm{g}^{-1}\right)\end{array}$ & $\begin{array}{c}\mathrm{CaO} \\
\left(\mathrm{mg} \cdot \mathrm{g}^{-1}\right)\end{array}$ \\
\hline WSA & 0.2 & 21.7 & 0.2 \\
WSA-T & 0.1 & 12.0 & 0.1 \\
\hline
\end{tabular}

Table 5. Basic characteristics of WSA and WSA-T.

\begin{tabular}{lccccc}
\hline Material & $\begin{array}{c}\text { Powder density } \\
\left(\mathrm{kg} \cdot \mathrm{m}^{-3}\right)\end{array}$ & $\begin{array}{c}\text { Matrix density } \\
\left(\mathrm{kg} \cdot \mathrm{m}^{-3}\right)\end{array}$ & $\begin{array}{c}\text { Blain fineness } \\
\left(\mathrm{m}^{2} \cdot \mathrm{kg}^{-1}\right)\end{array}$ & $\begin{array}{c}\text { BET specific surface } \\
\left(\mathrm{m}^{2} \cdot \mathrm{kg}^{-1}\right)\end{array}$ & $\begin{array}{c}\mathrm{pH} \text { value } \\
(-)\end{array}$ \\
\hline WSA & 827 & 2447 & 834 & 2755 & 11.7 \\
WSA-T & 896 & 2465 & 257 & 227 & 11.2 \\
\hline
\end{tabular}


content in the leachates is presented. Only trace amount of $\mathrm{Na}_{2} \mathrm{O}$ and $\mathrm{CaO}$ were identified. The content of $\mathrm{K}_{2} \mathrm{O}$ in the leachates was high. It was due to the high content of $\mathrm{K}_{2} \mathrm{O}$ in WSA and WSA-T materials as introduced in Table 3. The approximate limit of alkalis in Portland cement is $0.3-1.2$ mass \% [30]. They have been reported to react with some aggregates, causing disinte-gration of concrete, and affecting its rate of strength increase [31]. As presented in Table 1, the amount of alkalis $\left(\mathrm{Na}_{2} \mathrm{O}+\right.$ $\mathrm{K}_{2} \mathrm{O}$ ) in cement was 0.96 mass $\%$. The amount of alkalis in WSA and WSA-T (see Table 3) was 10.2 mass \% and 11.2 mass \% respectively. Due to that the upper limit for alkali content in blended binder was exceeded in all prepared blended mixes. Since the alkalis were found to be leachable from WSA and WSA-T, water treatment of raw ash could be considered as an effective way to eliminate the negative effects of high alkali content.

The results obtained from the modified Chapelle test of pozzolana activity are introduced in Table 8 . Based on the Chapelle test results, both studied ashes exhibited pozzolana activity. However, thermal treatment highly reduced the pozzolana activity of WSA-T. Looking at the Frattini test data presented in Figure 8, untreated WSA was pozzolana active, since the results obtained

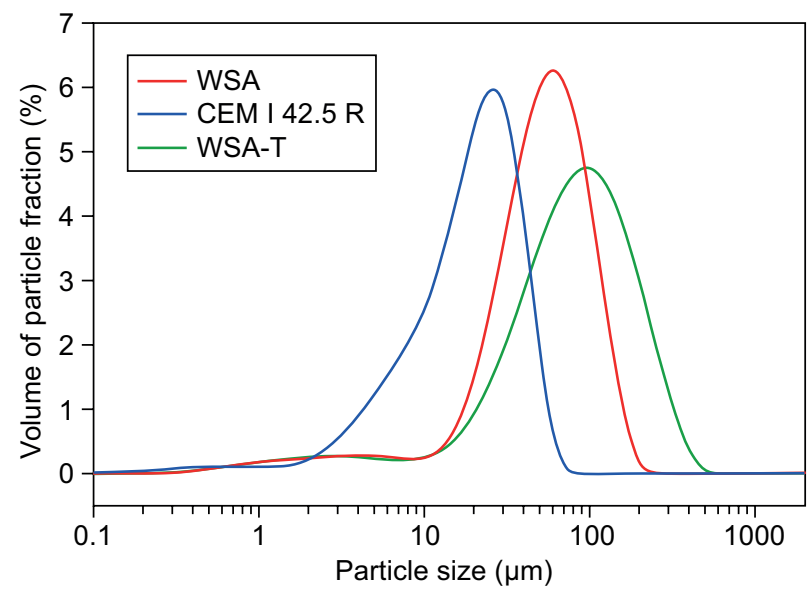

Figure 6. Particle size distribution - incremental curves.

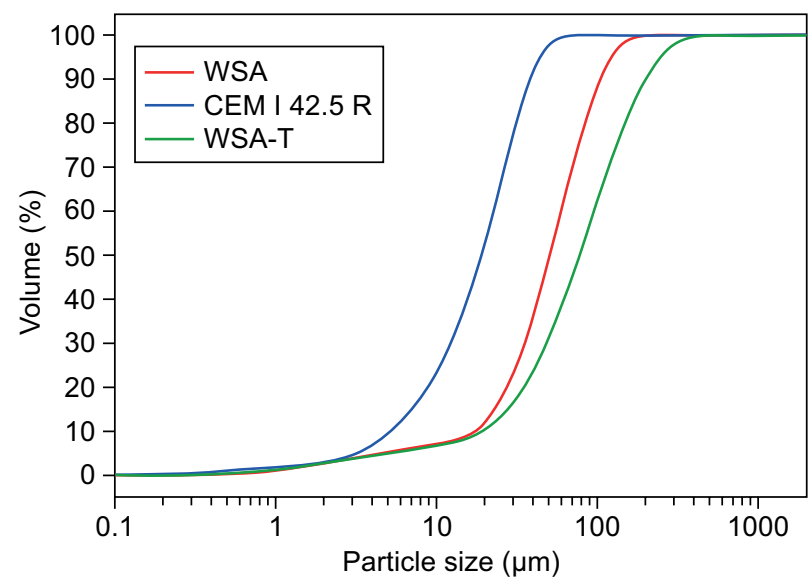

Figure 7. Particle size distribution - cumulative curves. for analyzed binder mixes were below the solubility curve of $\mathrm{Ca}(\mathrm{OH})_{2}$. On the other hand, WSA-T was not pozzolana active as apparent from measured data.

Properties of fresh paste mixes are presented in

Table 8. Pozzolana activity of wheat straw ash accessed by modified Chapelle tests.

\begin{tabular}{lc}
\hline Material & $\begin{array}{c}\text { Pozzolana activity } \\
\left(\mathrm{mg} \mathrm{Ca}(\mathrm{OH})_{2} \text { fixed by } 1 \cdot \mathrm{g}^{-1}\right)\end{array}$ \\
\hline WSA & 1726 \\
WSA-T & 1411 \\
\hline
\end{tabular}

Table 9. The blended binder exhibited improved workability compared to the reference cement paste. However, the initial and final setting times were significantly prolonged. This we assign to pozzolana reaction that was slower compared to the main hydration reactions of pure Portland cement.

The basic physical properties of the analyzed cement pastes with blended binder are presented in Table 10 . Both the bulk density and matrix density decreased with the increasing dosage of WSA in the paste. The total



Figure 8. Frattini test results.

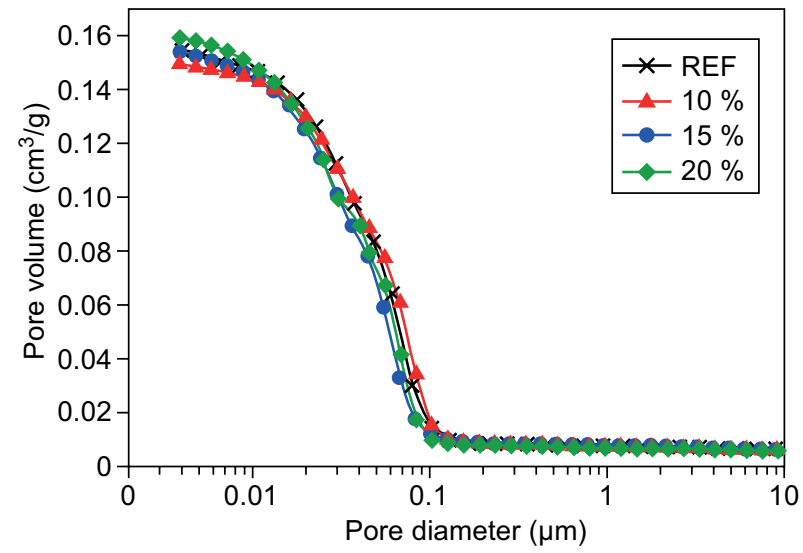

Figure 9. Pore size distribution of the tested pastes. 
open porosity for pastes containing 10 and 15 mass $\%$ of WSA was lower, compared to the reference paste mix. These data are in agreement with MIP results presented in Figure 9, where differences in pore size distribution were apparent for pores having diameters $<0.1 \mu \mathrm{m}$. The cumulative pore size distribution data showed a negligible volume of the biggest pores over $0.1 \mu \mathrm{m}$ in all pastes. This indicated a good durability potential of the analyzed materials.

The mechanical properties are summarized in Table 11. The strength activity index (SAI) was calculated as $\mathrm{SAI}=(\mathrm{A} / \mathrm{B}) \times 100$, where $\mathrm{A}$ was an average compressive strength of blended cement paste samples, and B an average compressive strength of control mortar samples. The compressive strength, bending strength and dynamic Young's modulus corresponded to the total open porosity data. For pastes containing 10 and 15 mass \% of WSA, the tested mechanical parameters were higher than for reference paste samples. It clearly documents the fact that WSA acted as an active mineral admixture contributing to material mechanical resistance. The SAI varied from $105.0 \%$ for paste with 10 mass $\%$ of cement replacement to $92.7 \%$ for paste with 20 mass \% of WSA. From this point of view, the pozzolana activity of WSA was proved.

The leaching test data obtained from leaching the examined pastes are introduced in Table 12. According to the standard EN 206-1 [32], the maximum acceptable amount of chlorides in concrete is 0.2 mass \%. Looking

Table 9. Properties of fresh paste mixes.

\begin{tabular}{lccc}
\hline Material & $\begin{array}{c}\text { Flow diameter } \\
(\mathrm{mm})\end{array}$ & $\begin{array}{c}\text { Initial setting } \\
\text { time }\left(\mathrm{kg} \cdot \mathrm{m}^{-3}\right)\end{array}$ & $\begin{array}{c}\text { Final setting } \\
\text { time }\left(\mathrm{m}^{2} \cdot \mathrm{kg}^{-1}\right)\end{array}$ \\
\hline Ref & 240 & 290 & 590 \\
$10 \%$ & 240 & 395 & 715 \\
$15 \%$ & 245 & 485 & 835 \\
$20 \%$ & 245 & 605 & 1135 \\
\hline
\end{tabular}

Table 10. Basic physical properties of the tested pastes.

\begin{tabular}{lccc}
\hline Material & $\begin{array}{c}\text { Bulk density } \\
\left(\mathrm{kg} \cdot \mathrm{m}^{-3}\right)\end{array}$ & $\begin{array}{c}\text { Matrix density } \\
\left(\mathrm{kg} \cdot \mathrm{m}^{-3}\right)\end{array}$ & $\begin{array}{c}\text { Total open } \\
\text { porosity }(\%)\end{array}$ \\
\hline Ref & 1652 & 2188 & 24.5 \\
$10 \%$ & 1650 & 2161 & 23.6 \\
$15 \%$ & 1627 & 2148 & 24.1 \\
$20 \%$ & 1564 & 2123 & 26.3 \\
\hline
\end{tabular}

at the measured data, the amount of leached chlorides from reference pastes was $0.4 \mathrm{mg} / \mathrm{g}$ what is 0.04 mass $\%$. Theses chlorides were probably contained in Portland cement used. The prepared cement blends met safely the above given requirement on chloride content since the amount of chlorides leached from the cement pastes containing WSA was around $1.0 \mathrm{mg} \mathrm{g}^{-1}$, i.e. 0.1 mass $\%$. The alkali content was low in all analyzed leaches indicating that the alkalis are inactivated in cement based matrix and hence, the alkali-silica reaction is generally avoided.

In Figure 10, the results obtained by STA are presented. In DTA curves, three significant endothermic heat flow peaks can be observed. The first peak in the temperature interval from $\sim 105^{\circ} \mathrm{C}$ to $\sim 250^{\circ} \mathrm{C}$ corresponded to the release of physically bound water from pores, together with the dehydration reactions due to the loss of water from calcium silicate hydrates $(\mathrm{C}-\mathrm{S}-\mathrm{H}$ gels) [33]. The peak temperature of the $\mathrm{C}-\mathrm{S}-\mathrm{H}$ and $\mathrm{C}-\mathrm{S}-\mathrm{A}-\mathrm{H}$ gels dehydration was for all the studied materials similar and varied from $170^{\circ} \mathrm{C}$ (paste with $15 \%$ of WSA) to $174^{\circ} \mathrm{C}$ (reference cement paste). This peak may be attributed to $\mathrm{C}_{2} \mathrm{ASH}_{8}$ decomposition. The reactions in this temperature interval were also associated with a significant mass loss. The second peak in the temperature interval from $\sim 420^{\circ} \mathrm{C}$ to $\sim 515^{\circ} \mathrm{C}$ represents the decomposition of Portlandite [34]. The peak temperature position was around $465^{\circ} \mathrm{C}$. The portlandite decomposition was also accompanied by a mass loss. From the thermogravimetry data, the portlandite content was estimated using a known value of the mass change during the decomposition of pure $\mathrm{Ca}(\mathrm{OH})_{2}$, which is $24.34 \%$ [35], and the mass change in the same temperature interval of the studied samples. The obtained results show (Table 13) that the amount of portlandite in the studied samples slightly decreased with the addition of WSA. This clearly documents the pozzolana activity of WSA that led to the decrease in

Table 12. Results of leaching tests for the examined pastes.

\begin{tabular}{lccc}
\hline Material & $\begin{array}{c}\mathrm{Na}_{2} \mathrm{O} \\
\left(\mathrm{mg} \cdot \mathrm{g}^{-1}\right)\end{array}$ & $\begin{array}{c}\mathrm{K}_{2} \mathrm{O} \\
\left(\mathrm{mg} \cdot \mathrm{g}^{-1}\right)\end{array}$ & $\begin{array}{c}\text { Chlorides } \\
\left(\mathrm{mg} \cdot \mathrm{g}^{-1}\right)\end{array}$ \\
\hline Ref & - & 0.8 & 0.4 \\
$10 \%$ & - & 0.9 & 1.0 \\
$20 \%$ & - & 1.1 & 1.1 \\
$30 \%$ & - & 1.1 & 1.1 \\
\hline
\end{tabular}

Table 11. Mechanical parameters of the tested pastes.

\begin{tabular}{lcccc}
\hline Material & $\begin{array}{c}\text { Compressive strength } \\
(\mathrm{MPa})\end{array}$ & $\begin{array}{c}\text { Flexural strength } \\
(\mathrm{MPa})\end{array}$ & $\begin{array}{c}\text { Young's modulus } \\
(\mathrm{GPa})\end{array}$ & $\begin{array}{c}\text { SAI } \\
(\%)\end{array}$ \\
\hline Ref & 64.5 & 10.3 & 20.5 & - \\
$10 \%$ & 67.7 & 11.2 & 21.0 & 105.0 \\
$15 \%$ & 65.2 & 11.1 & 20.6 & 101.8 \\
$20 \%$ & 59.8 & 10.2 & 19.4 & 92.7 \\
\hline
\end{tabular}

Ceramics - Silikáty 61 (4) 327-339 (2017) 
portlandite content. From the quantitative point of view, the values of portlandite content were in an agreement with data published by Pavlík et al. [36] who calculated portlandite content from STA performed for blended binder based on waste ceramic powder and Portland cement. The peaks in the temperature interval $\sim 600^{\circ} \mathrm{C}$ to $\sim 800^{\circ} \mathrm{C}$ corresponded to the decomposition of calcite $\left(\mathrm{CaCO}_{3}\right)$ and carbonated $\mathrm{C}-\mathrm{S}-\mathrm{H}$ gels. According to Peng and Huang [37], C-S-H phases start to decompose at around $560^{\circ} \mathrm{C}$ and are transformed into $\beta-\mathrm{C}_{2} \mathrm{~S}$ at around $600^{\circ} \mathrm{C}$ to $700^{\circ} \mathrm{C}$. The carbonation of $\mathrm{C}-\mathrm{S}-\mathrm{H}$ leads to the formation of vaterite, which seems to be an unstable type of calcium carbonate which decomposes typically between $500^{\circ} \mathrm{C}$ and $700^{\circ} \mathrm{C}$, at a lower temperature than calcite [36]. The peak temperatures of the calcite decomposition were identified around $720^{\circ} \mathrm{C}$. The peak temperatures of the vaterite decomposition were around $655^{\circ} \mathrm{C}$.

The results of FT-IR analysis are given in Figure 11. Assignment of the major absorption bands of tested pastes shows Table 14. FTIR spectra of the tested materials exhibited two distinct regions peaks for wave numbers $>3400 \mathrm{~cm}^{-1}$ and $<1500 \mathrm{~cm}^{-1}$. The first region is typical for $\mathrm{O}-\mathrm{H}$ stretching vibration assigned to portlandite

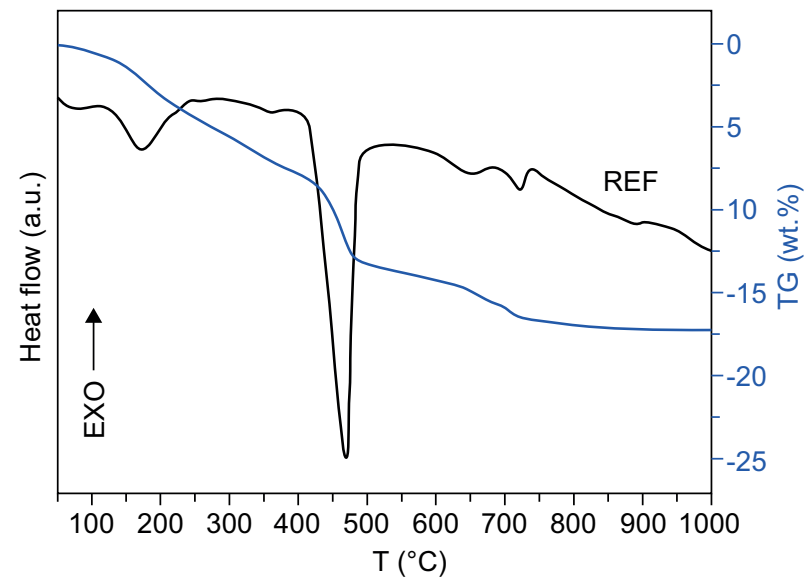

a) WSA

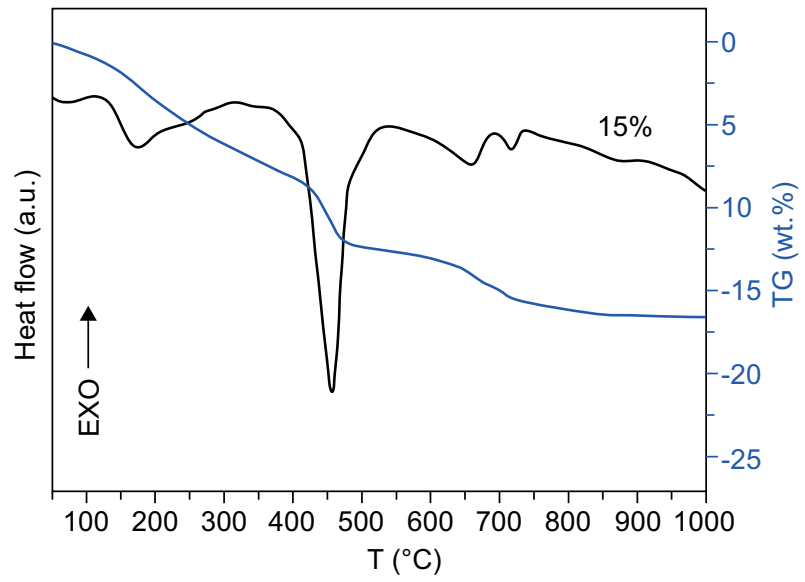

c) WSA-T $\left(3641 \mathrm{~cm}^{-1}\right)$. Calcite $\mathrm{C}=\mathrm{O}$ stretching vibrations were identified at 1480, 1414, and $872 \mathrm{~cm}^{-1}$. The intensity of absorption bands of these compounds decreased in the blended mixes compared with the reference cement paste. The largest peak in the presented spectra was at $951 \mathrm{~cm}^{-1}$. It corresponded to the formation of C-S-H phase (residual hatrurite $\mathrm{Ca}_{3} \mathrm{SiO}_{5}$ ). The peak at $400-500 \mathrm{~cm}^{-1}$ was assigned to the rocking motion of oxygen atoms bridging silicon atoms in siloxane bonds $\mathrm{Si}-\mathrm{O}-\mathrm{Si}$. The pozzolana reaction was proved with respect to portlandite consumption. The pastes with 10,15 and 20 mass $\%$ of wheat straw ash in the cement blend showed decrease in intensity of $\mathrm{O}-\mathrm{H}$ stretching vibration assigned to portlandite of $19.5 \%, 26.6 \%$, and $27.1 \%$ respectively.

\section{CONCLUSION}

Table 13. Portlandite content in the tested pastes.

\begin{tabular}{lcc}
\hline Material & $\begin{array}{c}\text { Mass change } \\
(\%)\end{array}$ & $\begin{array}{c}\text { Portlandite content } \\
(\%)\end{array}$ \\
\hline Ref & 4.5 & 13.1 \\
$10 \%$ & 3.7 & 10.8 \\
$15 \%$ & 3.5 & 10.2 \\
$20 \%$ & 3.4 & 9.9 \\
\hline
\end{tabular}

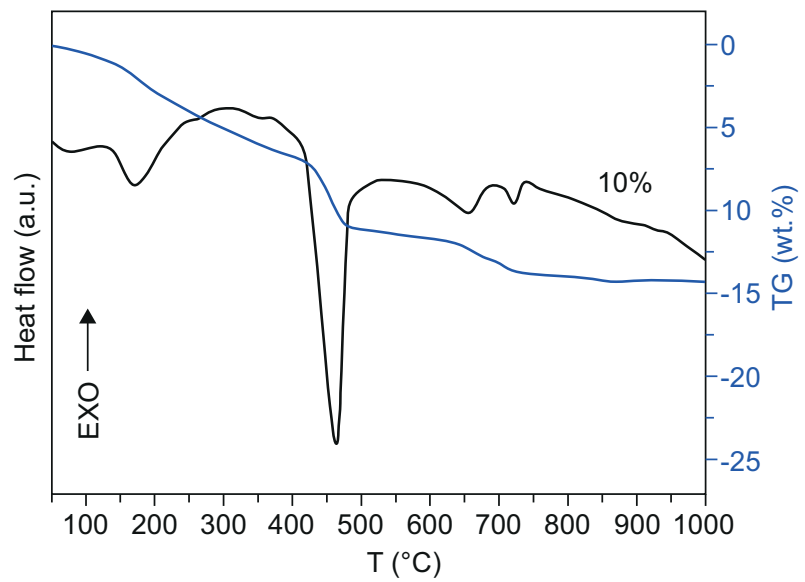

b) WSA

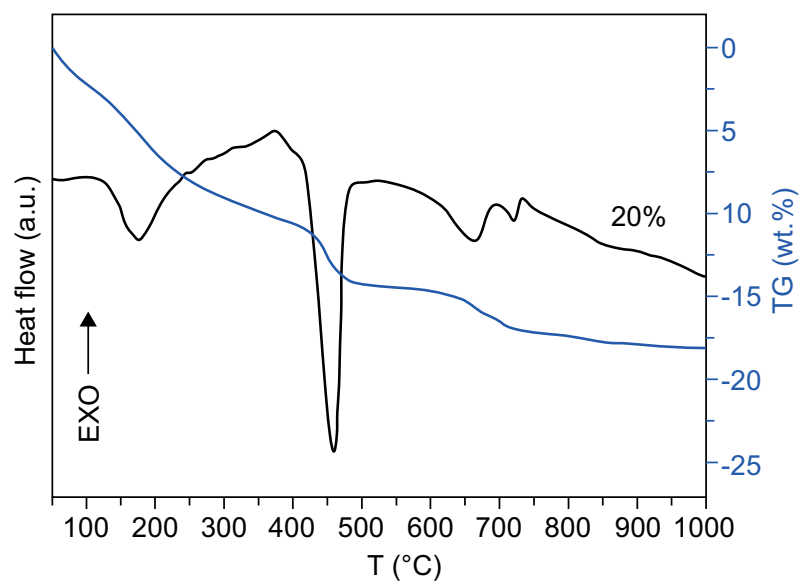

d) WSA-T

Figure 10. STA results. 




a)

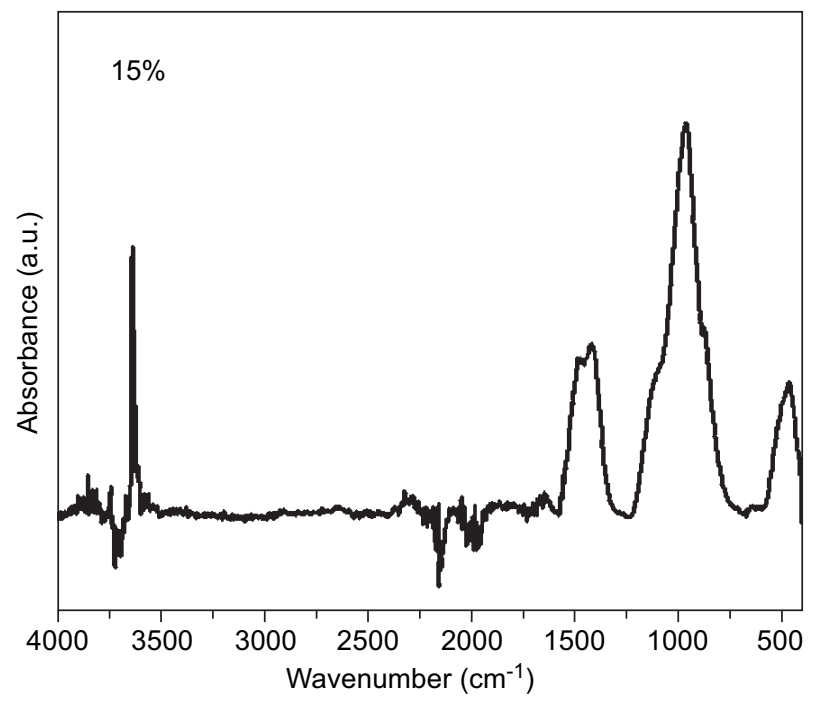

c)

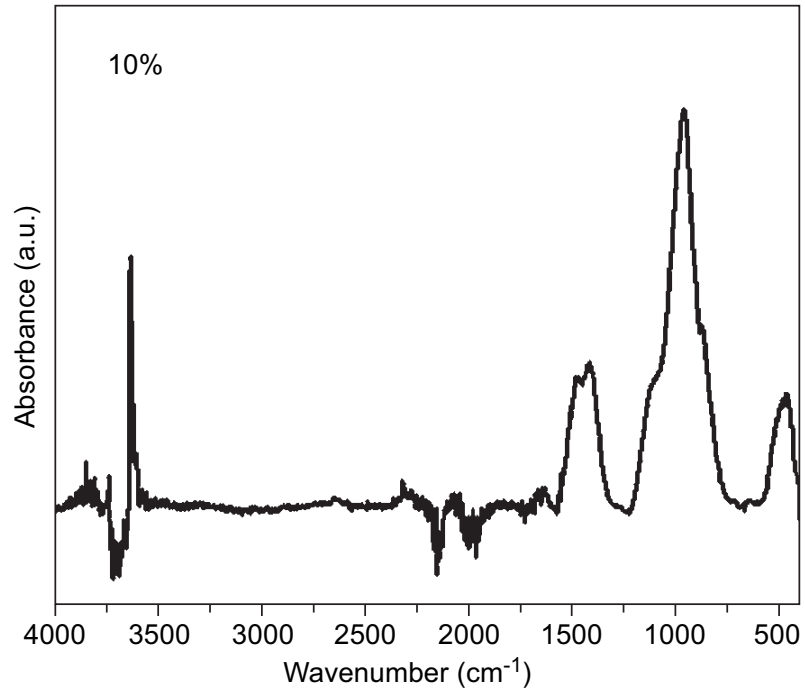

b)



d)

Figure 11. FT-IR spectra of the analyzed pastes.

Table 14. Assignments of the major absorption bands of cement pastes.

\begin{tabular}{lc}
\hline Wavenumber $\left(\mathrm{cm}^{-1}\right)$ & Assignment \\
\hline 3641 & $v(\mathrm{O}-\mathrm{H})$ in portlandite $\left(\mathrm{Ca}(\mathrm{OH})_{2}\right)[38]$ \\
1480,1414 & $v(\mathrm{C}=\mathrm{O})$ in calcite $\left(\mathrm{CaCO}_{3}\right)$ \\
951 & $v_{3}(\mathrm{Si}-\mathrm{O})$ in $\mathrm{C}-\mathrm{S}-\mathrm{H}$ phase [39] \\
872 & $v(\mathrm{C}=\mathrm{O})$ in $\mathrm{CO}_{3}^{2-}$ compounds, calcite [40] \\
640 & $v(\mathrm{Fe}-\mathrm{O}, \mathrm{Al}-\mathrm{O})$ in $\mathrm{C}_{4} \mathrm{AF}[41]$ \\
462 & $v_{4}(\mathrm{Si}-\mathrm{O}-\mathrm{Si})$ in $\mathrm{C}-\mathrm{S}-\mathrm{H}$ phase $[42]$ \\
\hline
\end{tabular}

This paper aimed at experimental assessment of pozzolana activity of wheat straw ash and evaluation of its potential for application as an active component of blended cements. Investigated combustion residua showed proper chemical, mineralogical, and phase composition upon its admixture to Portland clinker. SEM

analysis showed extremely large particles of WSA which were caused due to presence of amorphous phase sintered together with crystalline phase. On this account, WSA was milled for 15 minutes in a vibratory disc mill in order to improve its fineness. Both the chemical pozzalana activity tests proved a high reactivity of the investigated WSA in the presence of $\mathrm{Ca}(\mathrm{OH})_{2}$. The pastes based on the WSA-Portland cement blends exhibited improved mechanical properties, porosity and pore size distribution which clearly documented the pozzolana activity of WSA and benefits of its use in production of materials on cement basis. The reactivity of WSA was proved also by STA and FT-IR analysis that detected the decrease in Portlandite content in paste matrix with the increasing substitution of cement in a mix.

The thermal treatment of WSA was found to be not effective. Although the thermally treated WSA contained lower amount of carbon, thermal processing significantly reduced its specific surface and led to the coarser particle 
size distribution. Both these factors resulted in a lower pozzolana activity of the thermally treated WSA in case of the Chapelle test data. Moreover, the Frattini test results unconfirmed the expected pozzolanic characters of WSA-T.

In order to reduce the amount of alkalis in cement blends, water treatment of WSA was proposed as an effective tool to meet concrete standards requirements on alkali content. On the other hand, from the point of view of content of water soluble salts, the use of WSA in cement based materials represents a safe solution from the point of view corrosion resistance of a final product and use of steel reinforcement.

Based on the performed tests and summarizing the experimentally accessed data, the analyzed wheat straw ash represents promising material for production of cement and lime-based composites, where can partially substitute Portland clinker. From the environmental and economic point of view, the reuse of the analyzed combustion waste product in production of construction material is a highly beneficial solution respecting sustainability issues.

\section{Acknowledgment}

The authors gratefully acknowledge the financial support received from the Czech Science Foundation under project No. 17-02815S - Research and development of high performance composites containing biomass ash. This work was also supported by the Ministry of Education of the Czech Republic, Grant No. 20/2017 for specific university research.

\section{REFERENCES}

1. Regan C.M., Connor J.D., Segaran R.R., Meyer W.S., Bryan B.A., Ostendorf B. (2017): Journal of Environmental Management, 192, 171-183. doi:10.1016/j.jenvman. 2017.01.049

2. Evans A., Streyov V., Evans T.J. (2010): Sustainability considerations for electricity generation from biomass. Renewable and Sustainable Energy Reviews, 14, 14191427. doi:10.1016/j.rser.2010.01.010

3. Eisentraut A., Brown A. (2012). Technology Roadmap: Bioenergy for Heat and Power. International Energy Agency, Paris.

4. Toklu E. (2017): Biomass energy potential and utilization in Turkey. Renewable Energy, 107, 235-244. doi:10.1016/j. renene.2017.02.008

5. Kyriakopoulos G.L., G. Arabatzis G. (2016): Electrical energy storage systems in electricity generation: energy policies, innovative technologies, and regulatory regimes. Renewable and Sustainable Energy Reviews, 56, 10441067. doi:10.1016/j.rser.2015.12.046

6. Vassilev S.V., Baxter D., Andersen L.K., Vassileva C.G. (2013): An overview of the composition and application of biomass ash. 1. Phase-mineral and chemical composition and classification. Fuel, 105, 40-76. doi:10.1016/j.fuel. 2012.09.041

7. Izquierdo M., Querol X. (2012): Leaching behaviour of elements from coal combustion fly ash: an overview. Journal of Coal Geology, 94, 54-66. doi:10.1016/j. coal.2011.10.006

8. Jenkins B.M., Baxter L.L., Miles T.R. (1998): Combustion properties of biomass. Fuel processing technology, 54, 17-46. doi:10.1016/S0378-3820(97)00059-3

9. Salvo M., Rizzo S., Caldirola M., Novarja G., Canonico F., Bianchi M., Ferraris M. (2015): Biomass ash as supplementary cementitious material (SCM). Advances in Applied Ceramics, 114, S3-S10. doi:10.1179/174367611 5Y.0000000043

10. Vassilev S.V., Baxter D., Andersen L.K., Vassileva C.G. (2013): An overview of the composition and application of biomass ash: Part2. Potential utilisation, technological and ecological advantages and challenges. Fuel, 105, 19-39. doi:10.1016/j.fuel.2012.10.001

11. Cheah C.B., Ramli M. (2011): The implementation of wood waste ash as a partial cement replacement material in the production of structural grade concrete and mortar: An overview. Resources, Conservation and Recycling, 55, 669-685. doi:10.1016/j.resconrec.2011.02.002

12. Aprianti E., Shafigh P., Bahri S., Farahani J.N. (2015): Supplementary cementitious materials origin from agricultural wastes - A review. Construction and Building Materials, 74, 176-187. doi:10.1016/j.conbuildmat.2014. 10.010

13. Modolo R., Ferreira V., Tarelho L., Labrincha J., Senff L., Silva L. (2013): Mortar formulations with bottom ash from biomass combustion. Construction and Building Materials, 45, 275-281. doi:10.1016/j.conbuildmat.2013.03.093

14. Cheah C.B., Ramli M. (2012): Mechanical strength, durability and drying shrinkage of strctural mortar containing HCWA as partial cement replacement. Construction and Building Materials, 30, 320-329. doi:10.1016/j. conbuildmat.2011.12.009

15. Barauskas I., Kaminskas R., Liaudanskytè L. (2014): Influence of pozzolana additive on Portland cement in chloride and sulfate environment at low temperature. Ceramics - Silikáty, 58, 260-268.

16. El-Alfi E.A., Radwan, A.M., Abed El-Aleem S. (2004): Effect of limestone fillers and silica fume pozzolana on the characteristics of sulfate resistant cement pastes. Ceramics - Silikáty, 48, 29-33.

17. Lothenbach B, Scrivener K., Hooton R.D. (2011): Supplementary cementitious materials. Cement Concrete Research, 41, 1244-1256. doi:10.1016/j.cemconres.2010.12.001

18. ASTM C 192/C 192 M - 06 (2007). Standard practice for making and curing test specimens in the laboratory, ASTM.

19. ASTM C511-13 (2013). Standard Specification for mixing rooms, moist cabinets, moist rooms, and water storage tanks used in the testing of hydraulic cements and concretes, ASTM.

20. EN 196-6 (1989). Methods of testing cement; Determination of fineness, CEN.

21. EN 12457-2 (2002). Characterisation of waste - Leaching - Compliance test for leaching of granular waste materials and sludges - Part 2: One stage batch test at a liquid to solid ratio of $10 \mathrm{I} / \mathrm{kg}$ for materials with particle size below $4 \mathrm{~mm}$ (without or with size reduction), CEN.

22. EN 196-5 (2011). Methods of testing cement - Part 5: 
Pozzolanicity test for pozzolanic cement, CEN.

23. NF P 18-513 (2009). Pozzolanic Addition For Concrete Metakaolin - Definitions, Specifications And Conformity Criteria, AFN.

24. Pokorný J., Pavlíková M., Záleská M., Rovnaníková P., Pavlík Z. (2016): Coagulated silica - a- $\mathrm{SiO}_{2}$ admixture in cement paste. AIP Conference Proceedings, 1752, 040023. doi:10.1063/1.4955254

25. EN 196-3 (2008). Methods of testing cement - Part 3: Determination of setting times and soundness.

26. Gluth G.J.G, Hillemeier B. (2013): Pore structure and permeability of hardened calcium aluminate cement pastes of low w/c ratio. Materials and Structures, 46, 1497-1506. doi:10.1617/s11527-012-9991-2

27. EN 196-1 (2016): Methods of testing cement - Part 1: Determination of strength, CEN.

28. Pavlík Z., Fořt J., Záleská M., Pavlíková M., Trník A., Medved I., Keppert M., Koutsoukos P.G., Černý R. (2016): Energy-efficient thermal treatment of sewage sludge for its application in blended cements. Journal of Cleaner Production, 112, 409-419. doi:10.1016/j.jclepro. 2015.09.072

29. Meira G.R., Andrade C., Vilar E.O., Nery K.D. (2014): Analysis of chloride threshold from laboratory and field experiments in marine atmosphere zone. Construction and Building Materials, 55, 289-298. doi: 10.1016/j. conbuildmat.2014.01.052

30. Neville A.M. (2002). Properties of Concrete. fourth and final ed. Wiley, London.

31. Selman M.M., Ali A.M. (2012): The effect of alkalis on the properties of Portland cement. Anbar Journal for Engineering Sciences, 5, 25-38.

32. EN 206-1 (2014). Concrete - Part 1: Specification, Performance, Production and Conformity, CSI.

33. Heap M.J., Lavallée Y., Laumann A., Hess K.U., Meredith P.B., Dingwell D.B., Huismann S., Weise F. (2013): The influence of thermal-stressing (up to $1000{ }^{\circ} \mathrm{C}$ ) on the physical, mechanical, and chemical properties of siliceous-aggregate, high-strength concrete. Construction and Building Materials, 42, 248-265. doi: 10.1016/j. conbuildmat.2013.01.020

34. Janotka I. (2001): Hydration of cement paste with $\mathrm{Na}_{2} \mathrm{CO}_{3}$ addition. Ceramics - Silikáty, 45, 16-23.

35. Dweck J., Buchler P.M., Coelho A.C.V., Cartledge F.K., Hydration of a Portland cement blended with calcium carbonate. Thermochimica. Acta, 346, 105-113. doi:10.1016/S0040-6031(99)00369-X

36. Pavlík Z., Trník A., Kulovaná T., Scheinherrová L., Rahhal V., Irassar E., Černý R. (2016): DSC and TG Analysis of a Blended Binder Based on Waste Ceramic Powder and Portland Cement. International Journal of Thermophysics, 37, 32. doi:10.1007/s10765-016-2043-3

37. Peng G.-F., Huang Z.-S. (2008): Change in microstructure of hardened cement paste subjected to elevated temperatures. Construction and Building Materials, 22, 593-599. doi: 10.1016/j.conbuildmat.2006.11.002

38. Fernández-Carrasco L., Torrens-Martín D., Morales L.M. and Martínez-Ramírez S. (2012). Infrared Spectroscopy - Materials Science, Engineering and Technology, Chapter 19 Infrared Spectroscopy in the Analysis of Building and Construction Materials, InTech. doi:10.5772/36186

39. Horgnies M., Chen J.J., Bouillon C. (2013): Overview about the use of Fourier Transform Infrared spectroscopy to study cementitious materials. WIT Transactions on Engineering Sciences, 77, 251-262. doi:10.2495/MC130221

40. Bosch Reig F., Gimeno Adelantado J.V., Moya Moreno M.C.M. (2002): FTIR quantitative analysis of calcium carbonate (calcite) and silica (quartz) mixtures using the constant ratio method. Application to geological samples. Talanta, 58, 811-821. doi:10.1016/S0039-9140(02) 00372-7

41. Liang T., Nanru Y. (1994): Hydration products of calcium aluminoferrite in the presence of gypsum. Cement and Concrete Research, 24, 150-158. doi:10.1016/00088846(94)90096-5

42. Delgado A.H., Paroli R.M., Beaudoin J.J. (1996): Comparison of IR Techniques for the Characterization of Construction Cement Minerals and Hydrated Products. Applied Spectroscopy, 50(8), 970-976. doi:10.1366/000370 2963905312 